\title{
The Analysis of Cocoa Production in Manokwari (The Case Study in Asai and Mubraidiba Village)
}

\author{
Dominggus Marei \\ University Cenderawasih, Indonesia \\ ratangsarlota@yahoo.co.id
}

\begin{abstract}
The objectives of the research are used to determine: (1) the factors affecting the level of cocoa production in Asai and Mubraidiba village, Manokwari, (2) the difficulties faced by cocoa farmers there, and (3) the efforts to improve the productivity of cocoa in Manokwari. The analytical tool used is multiple linear regressions with a sample of 100 cocoa farmers. The results showed that negative factor that influence the level of cocoa production in Asai and Mubraidiba village in Manokwari is the wide of area (X1), age of plant (X2), the amount of fertilizer (X3) and total amount of the employee (X4). Among those several factors, the dominant factor that influence the level of cocoa production the most in Asai and Mubraidiba village, Manokwari is negative of wide area $\left(b_{1}\right)$ has a positive value in 6419 followed by the amount of negative number of employee $\left(b_{4}\right)$ also in positive value, 007. Then, age of plants (b2) has a negative value in -22 962, and the last negative factor is the amount of fertilizer $\left(b_{3}\right)$ also in negative, .001. The difficulties faced by farmers in Asai and Mubraidiba are the absence of mentoring. Mentoring is needed by the farmers to give them some solutions for their difficulties. The efforts to improve the productivity of cocoa in Manokwari are harvest, pruning, sanitation and fertilization that are called as PSPSP, in Bahasa means Panen Sering, Pemangkasan, Sanitasi dan Pemupukan.
\end{abstract}

Keywords: Production, wide area, age of plant, fertilizer, dan the employee

\section{Introduction}

The agricultural sector is providing the needs for the population and employees, also as the supplier of raw materials for the industry and as a source of the foreign exchange. The agricultural sector still has an important role in the national economy; it can be seen from the large number of population and employees that is absorbed in the agricultural sector, almost in 42.3 million people, or about 44.5 percent from the total amount of national employee. Besides, the agricultural sector is also becoming one component of the national development to alleviate poverty. The agriculture role in national development such as the formed of the employee, giving a contribution for Gross Domestic Product called as PDB (Produk Domestik Bruto), as the source of foreign exchange, industrial raw materials, sources of food and nutrition, and also giving the encouragement of other economic sectors movement. In a smaller area, agricultural development hopefully can be able to improve farmers' access on the production factors including capital resources, technology, seeds, fertilizer and distribution systems, thus have a direct impact in increasing the farmers income. West Papua has the potential land resources for agricultural development. Under the direction of spatial agriculture Atlas Indonesia, 1 : 1,000,000 from the 9.9 million hectares of land in the province of West Papua , covering an area of 2.7 million ha that is potentially for agriculture but only about 0.94 million ha ( $33 \%$ ), which is used for agriculture , (BPS Papua Barat , 2013 ). Manokwari is one of the districts in the Province of West Papua that is considerable potentially in the agricultural sub-sector. In accordance with Table 1 below shows the contribution of agriculture farming sub sector seen from the farmer total amount as perpetrators of agriculture.

\section{Table 1: The number of farmers in Manokwari in 2012}

\begin{tabular}{lll}
\hline NO & Sub Sector & The number of households \\
\hline 1 & Crops & 15.553 \\
2 & Horticultural & 16.092 \\
3 & Farming & 9.227 \\
4 & Animal Husbandry & 15.658 \\
5 & Fish Cultivation & 692 \\
6 & Fisheries & 1.335 \\
7 & Forestry & 1.366 \\
\hline
\end{tabular}

Source: BPS of Manokwai, 2013 
According to the number of households who work in the agricultural sub-sector, Horticultural has the largest number, 16092 households, followed by animal husbandry, crops, forestry, fisheries and the last is farming sub sector, 9227 households. Although the farming sub-sector has the smallest contribution but it actually has a large potential in regional development. Furthermore, there are so many areas in Manokwari that untapped maximally in agriculture sub sector. From those seventh mainstay commodities sub-sector in Manokwari, can be seen that the most widely cultivated crops is Cocoa, it is seen from the large number of households that is 5037 households and 46,650,614 $\mathrm{m} 2$ land area. As an export commodity, almost of the whole farming areas in surrounding slopes are planted with cocoa. From the data above, the cultivation of cocoa is very profitable, the income that is the cocoa farmers got can fulfill their daily needs in a long time since these plants can be picked at any time if the fruit has begun turning in to yellow and can be sold in small numbers because of the market demand. Therefore, cocoa farmers' daily needs are always filled with the income derived from the cultivation of cocoa. It cannot be denied that there are still many difficulties encountered in cultivating cocoa such as, seed low quality since it is not through a fermentation process, the purpose of fermentation is to establish a distinctive taste of chocolate and reducing the astringent and bitter taste in cocoa beans. With fermentation process, the cost of cocoa are higher compared than unfermented cocoa or wet cocoa.

\section{Literature Review}

The production function is the relationship between the factors of production and the achievement of the level of production, where the factors of production are known as input and the production number called as output (Sukirno, 2002). Triyanto (2006) explained that the company's goal in producing is to transform inputs into outputs, which can be formulated in the production function as:

$\mathbf{Q}=\mathbf{f} \mathbf{L}, \mathbf{M}$......)

where $\mathrm{Q}$ is the output of a particular item during a period, $\mathrm{K}$ is machinery (capital) used during that period, $\mathrm{L}$ is hours labor input, and $\mathrm{M}$ is the raw material used, and still many other variables that can affect production.

Meanwhile, Soekartawi (2002) states that the production function is the physical connection between the output produced with factors of production used to produce the physical product, a variable explained $(\mathrm{Y})$ and the variables explaining $(\mathrm{X})$, so that can be formulated as:

\section{$\mathbf{Q}=\mathbf{f}(\mathbf{X 1}, \mathbf{X} 2 \mathrm{X3} \ldots . . \mathrm{Xn})$}

where

$\mathrm{Q}=$ production level

$\mathrm{X} 1 \ldots \mathrm{Xn}=$ production factors

Production is the relationship between productions factors called as input with the products called as output. From the input provided by the company including the agricultural sector, how to obtain the maximum results appropriate with the level of technology at the time. The production function can be done in various ways to obtain certain outputs, one of them is labor intensive (more employee) which is done by many farming systems in Indonesia, or capital intensive that using more capital and machines which is done by the developed countries such as America, Japan (Deliarnov, 1994). A production function can give us an idea about the production that is technically efficient, means that all inputs are used in the completely minimal production or completely efficient. Meanwhile, according to Deliarnov (1994), from the input provided, every company wants to obtain the maximum results in accordance with the highest level of technology at the time. How to increase the production is: increasing the number of one of the inputs used, add some input (more than inputs used). Therefore, to obtain the optimal results need to combine the factors of production in the right way to achieve the highest possible efficiency, both in physically and economically (Mubyarto, 1989). In agriculture, the physical production generated by the operation of some production factors as well, such as land, seed, fertilizer, insecticides and employee. A rational producer will certainly combine the factors of production to achieve an efficient farming (Mubyarto, 1989), and it will not add the additional input if the resulting output is not profitable

Income Concept: Income is an opportunity to get the results from every effort, either directly or indirectly. Income received directly by any person who is directly related to the job, while the indirect income is income received through an intermediary (Bambang, 1994). Boediono (1992) suggests that the income of a citizen is the result of sales from the production factors. So the income is the sale result of production factors or its assets. In simple terms can be interpreted as capital receipts after deducting with the cost of production. The remuneration received as a number of production factors that is 
calculated for specified time. Besides, the number of data has the function to fulfill their daily needs and give satisfaction to the farmers to resume their production. Furthermore in the farming income there is a term known as gross income (gross farm income). The gross income of farming is the value of farming products within a specified time either sold or not. Soekartawi (2002) therefore, the farming income is covering all the result of production. Understanding these incomes can be concluded that the income is the acquisition value received by employees directly as the reward after completing a job.

\section{Methodology}

The location was chosen by the writer is on Asai and Mubraidiba village, Manokwari, started in October of 2014 until January of 2015. The samples used were 100 farmers. The data analysis use non-linear regression analysis to Cobb Douglas function.

$\hat{\mathrm{Y}}=\mathrm{AX}_{1}{ }^{\mathrm{b} 1} \mathrm{X}_{2} \mathrm{~b}^{\mathrm{b}} \mathrm{X}_{3}^{\mathrm{b} 3} \mathrm{X}^{\mathrm{b} 4}$

Where:

$\hat{Y}=$ cocoa commodities production level in Manokwari;

$\mathrm{X} 1=$ the wide area of cocoa commodities

$\mathrm{X} 2=$ the age of cocoa commodities

$\mathrm{X} 3$ = seed of cocoa commodities

$\mathrm{X} 4=$ Employee

\section{Finding}

Cocoa farmers in Asai and Mubraidiba, north Manokwari, West Papua, the number of respondents in this research are 100 cocoa farmers. Respondent genders are dominated by men, reaching $95 \%$. Cocoa farming is considered as a business that requires a lot of physical exertion so it is suitable for men who have the stronger physical ability than women. Meanwhile, women only helps if there is a leeway after doing their work as a housewife or at the harvest time. Age is one of the miners' employee productivity indicators since it has related with the level of farmer physical ability. They whose aged $<15$ years old are included in the category of has not been productive yet since they are student. 16-55 years old included in the productive age, while more than 56 years old is over age and surely their physical ability has declined. But in this research, they who in over age category around $30 \%$ are dominate works as cocoa farmers. Other category from the range age between 16-55 years old are contributed about $70 \%$. It happens because they have begun from productive age and still consider themselves still able to farming in this over age category since it is profitable for them.

The respondent education levels are mostly in Junior High Scholl (28\%) or high school (24\%). It shows that the level of education is quite good, especially with a good education and technology knowledge are really helping farmers in increasing the production of cocoa, innovating new variety ways to use the land intensification. And these things they gained from school. Mentoring for cocoa farmers has an important role in the production process. Due to the higher of existing technology (innovative findings) can simplify the production process in an effective and efficient time to make a good quality, the farmers highly need a mentor to give them direction, support and also when they are facing problems, a mentor can give them problem solving and the best solution. Moreover, many farmers are already harvesting then sold their cocoa still in a wet condition, whereas when cocoa is dried in a right step, the cost is almost in double profits, that is why a mentor is needed to achieve the progression. Unfortunately, there is no mentor in the location of this research. The result of regression analysis for Cobb Douglas function:

$\mathrm{Y}=439.220+6.419 \mathrm{X}_{1}+(-22.962) \mathrm{X}_{2}+(-.001) \mathrm{X}_{3}+.007 \mathrm{X}_{4}$

Regression coefficients wide area of 6419 means an increasing area in one hectare will increase the cocoa production in $6419 \mathrm{~kg}$. This is in line with the finding of the research which states that wide area has a positive influence of cocoa production (Slameto, 2000). The implication is, farmer has to increase their area to gain the increasing of their cocoa product or replace it with other crops cultivated such as coffee, coconut and clove. The fact happened on the ground is, farmer not only cultivate cocoa as the main commodity but also other commodities with an intercrop way. It is then suspected that the production of cocoa which has been declining due to the density of the number of plants cultivated in the area of land. Besides, the density of plants in one area of land allegedly also led to the cocoa will be infected by pests and diseases such as cocoa pod borer called as PBK (Penggerek Buah Kakao) and rot cocoa fruit known as BBK (Busuk Buah Kakao) due to high humidity. The coefficient of age plant regression is -22 962, means 
that every reduction of the plant age for one year, the cocoa production will also decrease in -22962 . If farmers survive with cocoa plants that are currently cultivated, then the cocoa production will decrease and the income of cocoa farmers will be smaller. In contrast to the results of research which states that the plant age has a positive effect on cocoa production (Slameto, 2000). This is because the age of cocoa plants cultivated today are old with an average age of cocoa plants is 19 years above the most productive age, 13-18 years (Wahyudi, 2009). The implication is, if farmers want to increase the cocoa production, needed to do replanting or rehabilitate the cocoa plant.

Regression coefficient of the amount of fertilizers is -0.001 , which means that every reduction in the amount of fertilizer in one kilogram, the production will be decreased into -0.001 . These results are not in line with the results of other studies that stated the use of fertilizers affect the production of cocoa (Slameto, 2000). The implication is, if farmers want to increase their cocoa production, the use of fertilizer is needed to do, but give too many fertilizer will decompose the plant. Although the actual use of fertilizer is needed because of the high levels of pests and diseases of cocoa pod borer and the rot cocoa fruit. The amount of employee regression coefficient is 0.007 , means that every additional employee in one person, the cocoa production will increase in 0.007 . The most responsive employee compared to other variables since it has the largest coefficient. This is in line with research states that employee inputs affect the production of cocoa (Slameto, 2000). The implication is, if cocoa farmers want to increase their cocoa production, need to increase the number of employee that is responsible in maintenance like pruning unproductive branches of the plant to make sure the humidity level is not too high, and get enough sunlight cocoa farm area. This is due to the current condition of cocoa plant that is infected by many pests and diseases that allegedly because of the highly humidity levels.

The Difficulties Faced by the Cocoa Farmers: The difficulties faced by the farmers in Asai and Mubraidiba village are the absence of mentoring. Mentoring for cocoa farmers has an important role in the production process. Due to the higher of existing technology (innovative findings) can simplify the production process in an effective and efficient time to make a good quality, the farmers highly need a mentor to give them direction, support and also when they are facing problems, a mentor can give them problem solving and the best solution. Moreover, many farmers are already harvesting then sold their cocoa still in a wet condition, whereas when cocoa is dried in a right step, the cost is almost in double profits, that is why a mentor is needed to achieve the progression. Unfortunately, there is no mentor in the location of this research. Besides, cocoa plants are often to get infected by the pests, if there is a mentor, there is also a solution for every problem.

The Efforts to Increase the Productivity of Cocoa: The efforts to improve the productivity of cocoa in Manokwari are harvest, pruning, sanitation and fertilization that are called as PSPSP, in Bahasa means Panen Sering, Pemangkasan, Sanitasi dan Pemupukan. Harvest must be done at least in every seventh to tenth days, the reason farmers should do a harvest often is to reduce the impact of PBK or cocoa pod borer, PBK will attack the cocoa pods that have already ripped, in the age of three to four months. Cocoa that just ripped is highly vulnerable by pests. In addition, the fruit that was not harvested soon, the sprout will appear and it cannot be sold. Cocoa fruit that are already ripped can be determined by looking at the changes in its skin color, cacao fruit can be picked after three to four months. Cacao fruit is green when it does not ripe yet, will change color to yellow after ripe. While the cocoa fruit is red, the color will change to orange when it is ripe. Furthermore, the most important thing to remember when picking cacao fruit is, not turning it by hand or kicked it. Picking cocoa should use scissors or machete. Leaving about two or three centimeters on the tree stalks is very important since the next cocoa pods will grow on these stalks. Pruning is needed to form a canopy on the cacao tree; it has to be formed in symmetrical to let the sun lights the tree and help the process of photosynthesis. Pruning can also maximize the flow of nutrients to the fruit and reduce insect pests and stimulate the growth of healthy interest bearing, because the PBK like in a cool place, dark and damp. The good form of cocoa trees have three or four main branches with the length stem about eighty centimeters and the heigh maximum of the tree is four meters. So it will improve the efficiency of the farmers' performance and trees productivity.

The sanitation or cleaning the farming regularly is a good way that is done by the cocoa farmers in Pekon, Lugusari to keep the farming healhty. This sanitation activities are including in two steps: First, clean the farming ground from leaves which are falling, it is intended to kill the PBK pest's life cycle that attached to the leaf. The second activity is to bury the fruits are affected by the disease from the farming area. The farmer group is cleaning the farming ground by leaving a layer of leaves. It has two goals: first, leaves actually a home for insect and other organisms, such as ants which is turned out to be the natural enemies 
of PBK. Second, if the ground is left openly, the sun will be directly shining on the soil surface that help the soil to uptake the nutrients for the tree. Fertilization is done twice in a year, at the beggining of the rainy season and the end of the rainy season. Farmers use two kinds of fertilizers to support the productivity of cocoa pods. Compound fertilizer containing nitrogen, phosphate and potash as well as organic fertilizer derived from animal feces or decaying skin cocoa fruit. Organic fertilizer here is known can accelerate the decomposition of the compound fertilizers as well as to strengthen the plant antibodies. Fertilization is done by digging up the area around the tree with a diameter of $70 \mathrm{~cm}$ from the point of growing trees. Fertilization in flat areas is different from fertilization in areas that have a slope. For skewed area quite a semicircular upper course sprinkled with fertilizer, it has the intention to keep the fertilizer is not carried away by water during the rainy season, only the top that are sprinkled with fertilizer also with the intention that if fertilizers carried away by the water, heavy rain will be directly captured by tree below.

\section{Conclusion}

The Results of this study has several conclusions. Factors that influence the level of cocoa production in Asai and Mubraidiba village, Manokwari is the wide area, age plant, the amount of fertilizer and the employee. The employee is a dominant factors in influencing the level of cocoa production in Asai and Mubraidiba village, Manokwari. The difficulties faced by farmers in Asai and Mubraidiba are the absence of mentoring. Mentoring is needed by the farmers to give them some solutions for their difficulties. The efforts to improve the productivity of cocoa in Manokwari are harvest, pruning, sanitation and fertilization.

\section{References}

Boediono. (1992). Pengantar Ekonomi Makro, BPFE-UGM, Yogyakarta.

Bambang, S. (1994). Analisis Laporan Keuangan, LP3ES-Jakarta.

Delianov (1994). Pengantar Ekonomi Makro, Jakarta, UI Press.

Mubyarto ( 1989). Pengantar Ilmu Ekonomi Pertanian. Edisi ketiga. LP3ES. Jakarta.

Slameto. (2000). Agrikultur, LPN-IPB-Bogor.

Soekartawi (2002). Prinsip Dasar Ekonomi Pertanian: Teori dan Aplikasi, Edisi ke 2. PT RajaGrafindo Persada, Jakarta.

Sukirno, S. (2002). Pengantar Teori Mikro Ekonomi. Edisi Ketiga. PT Raja Grafindo Persada. Jakarta.

Triyanto, J. (2006). Analisis Produksi Padi di Jawa Tengah. Pasca Sarjana Universitas Diponegoro Semarang. Tesis (di publikasikan melalui www.geogle.com).

Wahyudi, T.P. (2009). Sejarah dan Prospek dalam panduan lengkap Kakao (Wahyudi et al) Penebar Swadaya, Jakarta. 